\title{
PENGGUNAAN INTERNET SEBAGAI MEDIA DALAM PEMBELAJAN \\ BAHASA INDONESIA KELAS VII DI SMP NEGERI 4 SINGARAJA
}

\author{
Kd Zervina Andryani ${ }^{1}$, SAP Sriasih ${ }^{2}$, I Wyn Artika ${ }^{3}$ \\ Prodi Pendidikan Bahasa Indonesia, Jurusan Bahasa Sastra Indonesia dan \\ Daerah, \\ Universitas Pendidikan Ganesha \\ Singaraja, Indonesia \\ e-mail: \{kadek.zervina.andryani ${ }^{1}$ putu.sriasih ${ }^{2}$ wayan.artika $\} @$ undiksha.ac.id
}

\begin{abstract}
ABSTRAK
Penelitian ini bertujuan untuk mengkajijenis media internet dan penggunaannya dalam pembelajaran bahasa Indonesia di SMP Negeri 4 Singaraja. Penelitian ini menggunakan rancangan penelitian deskriptif kualitatif.Pada penelitian ini subjek penelitian yang digunakan adalah gurubahasa Indonesia, siswa kelas VII A1 dan VII A2, serta internet.Sedangkan objek penelitian ini adalah jenis media internet dan penggunaan internet sebagai media pembelajaran. Jenis media internet dalam pelajaran bahasa Indonesia di SMP Negeri 4 Singaraja dilihat dari jenis media yang sering diguankan oleh guru pelajaran bahasa Indonesia. Sedangkan penggunaan internet sebagai media dalam pembelajaran bahasa Indonesia di SMP Negeri 4 Singaraja dilihat dari cara guru menggunakan media internet dalam pembelajaran. Hasil penelitian didapatkan dengan menggunakan metode observasi, dokumentasi, dan wawancara. Analisis data dilakukan dengan cara reduksi data, penyajian data, dan penarikan kesimpulan. Adapun hasil penelitian, yaitu (1) Jenis media internet yang digunakan adalah video dan teks, (2) video yang digunakan terdiri dari video cerita fantasi, video deskripsi, dan video prosedur. Sedangkan teks yang digunakan yaitu: teks deskripsi dan teks prosedur, (3)penggunaan media video digunakan dengan cara ditayangkan dan media teks digunakan sebagai contoh dalam bentuk hardcopy, (4) penggunaan internet sebagai media yang dilakukan oleh guru dan peserta didik kelas VII A1 dan VII A2 pada mata pelajaran bahasa Indonesia di SMP Negeri 4 Singaraja.
\end{abstract}

Kata kunci: Media, internet, video, teks

\begin{abstract}
This study aims to examine the type of internet media and it used in learning of Bahasa Indonesia at SMP Negeri 4 Singaraja. This study used a qualitative descriptive research design. In this study, the subjects of research who used are Indonesian teacher, students of VII A1 and VII A2, and internet media. While the object of this research is the types of internet media and using the internet as a learning media. The type of internet media in Indonesian language learning at SMP Negeri 4 Singaraja is seen from the type of media that is often used by Indonesian teacher. While the use of the internet as a medium in learning the Indonesian language in SMP Negeri 4 Singaraja is seen from the teacher way to use internet media in learning. The results of the study were obtained using the observation method, documentation, and interviews. The data were analyzed is done by reducing data, presenting data, and conclusions. The results of the study, namely (1) The types of internet media used are video and text, (2) the videos used to consist of fantasy story video, description video, and video procedures. While the text used is: description text and procedure text, (3) the used of video media is used by broadcasting and media
\end{abstract}


text is used as an example in hardcopy, (4) the used of the internet as media carried out by teacher and students of VII A1 and VII A2 on Indonesian language subject at SMP Negeri 4 Singaraja.

\section{Keywords:Media,internet,video,text}

\section{PENDAHULUAN}

Dalam dunia pendidikan sering kali muncul masalah yang berhubungan dengan proses pembelajaran yaitu lemahnya proses pembelajaran (Setyani, 2010:1). Dalam proses pembelajaran, seorang guru memiliki peranan penting demi tercapainya kegiatan pembelajaran di sekolah. Guru menjadi ujung tombak terciptanya proses pembelajaran (Talika, 2016:1). Meskipun guru mempunyai kecerdasan tanpa didukung dengan media pembelajaran yang baik maka proses pembelajaran itu akan menjenuhkan dan kurang menarik bagi siswa. Terkait dengan kemajuan teknologi maka dalam pembelajaran perlu adanya media pembelajaran yaitu internet.

Jagad raya internet tercipta oleh suatu ledakan tak terduga di tahun 1969, yaitu dengan lahirnya ARPANET, suatu proyek eksperimen dari Kementerian Pertahanan Amerika Serikat bernama DARPA (Departemen of Defense Advanced Research Projects Agency).Misi awalnya sederhana, yaitu mencoba menggali teknologijaringan yang dapat menghubungkan para peneliti dengan berbagai sumber daya jauh seperti sistem komputer dan pangkalan data yang besar (Rahmadan, 2011). Jaringan ini kemudian berkembang untuk menghubungkan berbagai jaringan akademis lainnya yang terdiri atas universitas dan konsorsiumkonsorsium riset. Dari perkembangan tersebut muncullah internet sebagai tombak baru komunikasi setiap orang. Indonesia baru bisa menikmati layanan Internet komersial pada sekitar tahun 1994. Sebelumnya, beberapa perguruan tinggi seperti Universitas Indonesia telah terlebih dahulu tersambung dengan jaringan internet melalui gateway yang menghubungkan universitas dengan network di luar negeri (Rohaya, 2008:3).

Dewasa ini internet sangat bermanfaat bagi setiap orang di dunia. Pemanfaatan internet sudah banyak berpengaruh bagi setiap orang. Manfaat yang sangat besar dalam kehidupan remaja untuk meningkatkan pengetahuan serta menambah wawasan remaja tentang komunikasi yang baik secara langsung dan sudah terjalin dengan orang lain. Internet mampu memberikan banyak informasi yang dibutuhkan oleh setiap remaja dan dapat mempermudah komunikasi dari jarak yang sangat jauh tanpa harus dengan bertatap muka secaralangsung (Talika, 2016). Begitu juga dengan dunia pendidikan internet sudah semakin banyak digunakan. Disadari bahwa kehadiran teknologi internet dan pemanfaatannya dalam sebuah lembaga pendidikan adalah sebagai media atau sumber pembelajaran yang dapat dimanfaatkan oleh masing-masing guru dan siswa. Maka hadirnyafasilitas teknologi internet di dunia pendidikan telah memberikan kesempatan yang lebih luas kepada seluruh pembelajaran, khususnya para guru guna memanfaatkannya untuk kebutuhan pembelajaran. Dengan hadirnya fasilitas internet telah memberikan kemudahan tersediri bagi guru dan siswa untuk mencari referensi-referensi menunjang keperluan pembelajaran (Kaliky, 2013).Oleh karena sudah hadirnya fasilitas internet di dunia pendidikan, maka sumber pembelajarannya berangsur-angsur mulai mengalami peningkata.Para siswa sudah mulai keluar dari kesulitan mencari referensi untuk kebutuhan pembelajaran.

Media pembelajaran berbasis internet sangat memudahkan guru untuk meciptakan suasana belajar yang efektif. Guru mencari bahan pembelajaran bersumber dari internet seperti halnya video, teks, gambar dan bahan internet lainnya (Kaliky, 2013). Jenis media internet 
yang diguanakan akan sangat membantu setiap proses pembelajaran. Media pembelajaran berbasis internet ini menguntungkan setiap pembelajar di dunia. Khususnya dalam pembelajaran bahasa Indonesia media berbasi internet sangat dibutuhkan untuk setiap sub materi pembelajaran. Seperti halnya dengan materi teks prosedur, unsur-unsur surat, dan sub materi yang lain. Namun, pada kenyataannya dengan penggunaan media berbasisi internet masih sangat sedikit digunakan oleh setiap sekolah. Banyak kendala yang sering mereka alami menggunakan fasilitas internet. Jaringan yang terkadang bermasalah mengakibatkan jangkauan internet sangat lambat dan susah untuk didapatkan. Selain itu guruguru juga masih sangat hawam dengan teknologi internet. Internet tidak bisa diterapkan di sekolah-sekolah yang masih kurang fasilitasnya. Namun, pada penelitian di SMP Negeri 4 Singaraja sekolah sudah mulai menggunakan internet sebagai berbagai sumber belajar untuk membantu siswa mendaptakan materi tambahan. Guru-guru juga sudah tidak asing lagi menggunakan internet karena sudah terbiasa.

Berdasarkan latar belakang masalah yang telah diuraikan, maka penulis mengajukan rumusan masalah sebagai berikut. 1) Jenis media apakah yang dapat digunakan guru terkait dengan internet dalam pembelajaran bahasa Indonesia di kelas VII SMP Negeri 4 Singaraja?2) Bagaimanakahpenggunaan media internet dalam pembelajaran bahasa Indonesia di kelas VII SMP Negeri 4 Singaraja?Berdasarkan rumusan masalah di atas, adapun tujuan yang ingin dicapai dalam penelitian ini adalah sebagai berikut. Tujuan Umum: Dalam penelitian ini tujuan umum yang ingin dicapai untuk menambah pengetahuan dan wawasan mengenai penggunaan internet sebagai media pembelajaran bahasa Indonesia. Tujuan Khusus: 1) Mendeskripsiskan jenis media yang digunakan guru terkait dengan internet dalam pembelajaran bahasa Indonesia di kelas VII SMP Negeri 4 Singaraja.2) Mendeskripsikan penggunaan media internet dalam pembelajaran bahasalndonesia di kelas VII SMP Negeri 4 Singaraja.

\section{METODE PENELITIAN}

Metode penelitian pada prinsipnya adalah prosedur atau cara yang ditempuh dalam penelitian (Wendra, 2016:52). Prosedur atau cara yang digunakan pada penelitian ini akan membantu peneliti mempermudah pekerjaan untuk mencapai tujuan yang dikehendaki. Pada bagian ini, yang diuraikan adalah (1) rancangan penelitian, (2) jenis dan sumber data, (3) metode pengumpulan data, (4) metode dan analisis data. Masing-masing unsur tersebut akan diuraikan berikut ini.

Rancangan penelitian pada penelitian ini adalah rancangan deskriptif kualitatif. Penelitian deskriptifkualitatif dilakukan untuk mengumpulkan data yang menggambarkan penggunaan media berbasis internet. Bogdan dan Taylor (dalam Esti, 2012:7) mendefinisikan penelitian kulitatif sebagai prosedur penelitian yang menghasilkan data deskriptif berupa kata-kata tertulis atau lisan dari orang-orang dan perilaku yang dapat diamati, pendekatan ini diarahkan pada latar dan individu secara holistik (utuh).Jadipenelitian deskriptif kualitatif ini hanya untuk mendeskripsikan dan mengetahui mengenai penggunaan internet sebagai mediadalam pembelajaran bahasa Indonesia.

Metode merupakan sebuah langkah atau cara yang digunakan peneliti dalam mengumpulkan data-data yang diinginkan. Metode pengumpulan data adalah caracara yang digunakan peneliti dalam mengumpulkan data peneliti (Suandi \& Dkk, 2016:16).Dalam penelitian ini pengumpulan data dilakukan untuk mendapatkan data yang diinginkan, hal tersebut bertujuan untuk menjawab permasalahan yang dikaji dalam penelitian.Metode yang digunakan dalam penelitiana ini meliputi metode observasi, dan metode wawancara, serata metoe dokumentasi.

Instrumen penelitian adalah alat yang sifatnya lebih teknis dan oprasional untuk memperoleh data (Suandi, dkk, 2016:16). Secara fungsional penerapaninstrumen penelitian adalah untuk memperoleh data 
yang diperlukan ketika peneliti sudah menginjak pada langkah pengumpulan informasi di lapangan (Suandi, 2008:75). Instrumen yang digunakan dalam penelitian ini adalah pedoman observasi. Pedoman observasi digunakan untuk mengumpulkan data dan mencatat segala kejadian selama penggunaan media internet dalam pembelajaran bahasa Indonesia di SMP Negeri 4 Singaraja. Pada penelitian ini juga terdapat instrumen berupa pedoman wawancara, untuk mengetahui jenis media internet yang sering digunakan oleh guru.

\section{HASIL PENELITIAN}

Dalam bab ini diuraikan hasil penelitian dan pembahasan yang telah dilakukan. Hasil penelitian ini adalah halhal yang berkenaan dengan (1) jenis media internet yang digunakan guru dalam pembelajaran bahasa Indonesia di kelas VII SMP Negeri 4 Singaraja dan (2) penggunaan media internet dalam pembelajaran bahasa Indonesia kelas VII di SMP Negeri 4 Singaraja.

Hasil penelitian ini berdasarkan rumusan masalah, yaitu jenis media internet yang digunakan oleh guru di kelas VII A1 dan VII A2 SMP Negeri 4 Singarja dan penggunaan internet sebagai media dalam pembelajaran bahasa Indonesia. Rumusan masalah pertama dilihat dari seringnya media internet yang digunakan oleh guru, sedangkan rumusan masalah kedua dilihat dari cara penggunaan media internet tersebut. Berikut uraian temuan yang telah diperoleh selama pelaksanaan penelitian.

Dilihat dari hasil wawancara yang dilakukan bersama guru bahasa Indonesia bahwa,proses pembelajaran sangat baik dilaksanakan karena dipengaruhi oleh beberapa faktor yang ada di dalamnya. Dalam hal ini, salah satunya adalah proses transfer ilmu kepada peserta didik yang menjadi bahan pembaharuan secara berkelanjutan. Suatu materi tidak dapat diserap secara sempurna oleh peserta didik apabila pesan yang disampaikan tidak dapat disajikan secara baik.Penggunaan video sebagai bahan bantu mengajar memberikan satu pengalaman baru kepada setiap pelajar.

Dalam kegiatan belajar-mengajar, guru memanfaatkan internet sebagai media pembelajaran. Guru di kelas VII A1 dan VII A2 SMP Negeri 4 Singaraja menggunakan jenis media internet yaitu: video dan teks dalam pembelajaran. Video dan teks digunakan untuk menarik peserta didik untuk lebih mengikuti pembelajaran dengan baik. Dari kedua jenis media yang digunakan oleh guru tersebut, guru menjadi mudah memberikan pembelajaran kepada siswa. Media yang digunakan oleh guru seperti video dan teks bisa melengkapi pembelajaran konvesional. Selain itu, media video dan teks yang bersumber dari internet membantu guru menghadapi kendala-kendala yang dihadapi.

Media video dan teks,yang digunakan oleh guru yaitu: video cerita fantasi, video deskripsi, dan video prosedur. Ketiga video tersebut digunakan oleh guru untuk membantu siswa lebih tertarik mengikuti pembelajaran dan menambahkan minat siswa dalam pembelajaran. Siswa lebih memahami pembelajaran dengan adanya media yang menarik untuk digunakan. Selain media video, teks juga digunakan sebagai media pembelajaran yang digunakan guru untuk contohdalam menyampaikan materi. Media teks yang digunakan ada dua yaitu: media teks deskripsi dan teks prosedur. Video yang diunduh dari sumber internet dapat memudahkan guru dalam pembelajaran. Sedangkan teks didapatkan melaui sumber google. Dengan adanya video dan teks, guru dapat membantu siswa untuk memahami setiap pembelajaran yang digunakan. Berikut jenis video yang sering digunakan oleh guru dalam pembelajaran. Guru sering mengunakan aplikasi youtube untuk mencari video pembelajaran. Youtube merupakan aplikasi yang bersumber dari internet dengan menggunakan jaringan untuk menjalankanya. Berikut video yang digunakan oleh guru saat mengajar di kelas VII A1 dan VII A2.

Cerita fantasi meupakan cerita yang isinya bernuansa keajaiban dengan pemunculan tokoh-tokoh unik seperti robot, 
pohon, ataupun batu yang bisa berbicara atau berperilaku seperti manusia.Interaksi yang terjadi antara tokoh memunculkan halhal di luar pemahaman logika manusia (Yanner, 2018:100).Ciri utama cerita fantasi dapat dilihat dari tokoh-tokoh dan tempatnya yang merupakan hasil fantasi yang tidak ada di kehidupan nyata (Kurniawan,2014:39). Hampir sebagian besar unsur intrinsik dalam teks cerita fantasi memunculkan hal-hal yang unik, aneh, dan mengherankan.Selain itu teks cerita fantasi pun mengandung nilai pendidikan karakter yang cukup kuat dalam memberi inspirasi terhadap siswa untuk belajar tentang nilai sopan, peduli, jujur, dan bertanggung jawab.Jadi, cerita fantasi bukan hanya menulis teks sejenis fabel atau legenda legenda tapi ada bentuk lainnya yang dapat ditulis.

Guru menggunakan cerita fantasi sebagai salah satu video dalam pembelajaran yang mampu membantu siswa dalam pembelajaran dan memotivasi siswa lebih mengikuti pembelajaran. Guru mencari cerita fantasi melalui internet yaitu dengan membuka jaringan google terlebih dahulu lalu mencari youtubeuntuk membuka video yang diinginkan guru. Guru menggunakan video cerita fantasi sebagai contoh yang diberikan kepada sisiwa. Jenis cerita fantasi yang digunakan oleh guru yaitu "Sang Putri dan Sang Nada".

Video digunakan untuk menarik peserta didik. Berikut jenis video yang sering digunakan oleh guru dalam pembelajaran. Guru sering mengunakan aplikasi youtube untuk mencari video pembelajaran. Youtube merupakan aplikasi yang bersumber dari internet dengan mengunakan jaringan untuk menjalankanya. Berikut video yang digunakan guru saat mengajar.

Guru menggunakan cerita fantasi sebagai salah satu video dalam pembelajaran yang mampu membantu siswa dalam pembelajaran dan memotivasi siswa lebih mengikuti pembelajaran. Guru mencari cerita fantasi melalui internet yaitu dengan membukan jaringan google terlebih dahulu lalu mencari youtube untuk membuka video yang guru inginkan. Tidak hanya cerita fantasi yang digunakan oleh guru namun video deskripsi juga digunakan oleh guru saat pembelajaran.

Dalam pembelajaran mendeskripsikan suatu objek, selain buku ajar yang digunakan sebagai jenis media pembelajaran. Guru menggunakan jenis media video yang bersumber melalui internet dalam pembelajaran. Video deskripsi tersebut sebagai bahan ajar untuk diperlihatkan kepada siswa cara mendeskripsikan objek. Guru mencari video deskrispi melalui jaringan internet yang secara langsung digunakan oleh guru atau online. Dalam pembelajaran online tersebut, guru mencari video melalui youtube dan diberikan kepada siswa sebagai contoh pembelajaran.

Dalam pembelajaran yang berlangsung guru menggunakan buku ajar dalam pembelajaran. Selain itu guru menggunakan video dalam pembelajaran. Guru menggunakan video dalam pembelajaran agar memotivasi setiap siswa lebih giat dalam belajar. Selain itu guru juga lebih kreatif dalam membuat media pembelajaran tidak bergantung pada buku ajar. Dalam pembelajaran teks prosedur guru juga menggunakan video sebagai media pembelajaran. Guru menggunakan jenis media pembelajaran video agar siswa lebih mengetahui cara membuat sesuatu dan cara menyusuin dengan sistematis pembuatan kerajinan dengan baik.

Media video yang digunakan oleh guru ialah video tentang "cara membuat kerajinan". Dalam video tersebut terdapat cara-cara membuat kerajinan. Guru menggunakan video tersebut karena guru ingin mengajak siswa lebih fokus terhadap video yang diguankan. Video tersebut dapat menarik minat siswa untuk lebih tertarik dalam pembelajaran teks prosedur.

Dengan adanya video tersebut guru membuktikan bahwa media pembelajaran video sangat membantu dalam berlangsungnya proses belajar-mengjar. Media video yang bersumber dari internet dapat membantu guru secara langsung memberikan materi yang kurang dipahami oleh siswa. Dengan bantuan media pembelajaran jenis video ini siswa menjadi termotivasi untuk lebih giat dalam belajar. 
Dari hasil yang diperoleh penulisdi SMP Negeri 4 Singaraja, pada pembelajaran yang dilaksanakan oleh guru bahasa Indonesia kelas VII A1 dan VII A2, guru sering menggunakanmedia video. Selain media video yang digunakan oleh guru, media teks juga digunakan dalam pembelajaran. Media teks yang digunakan bersumber melalui internet. Tidak hanya dari internet media teks juga bisa berupa buku ajar yang digunakan oleh guru. Dengan adanya internet guru mampu mendapatkan jenis media yang sangat beragam. Teks sebagai media dalam pembelajaran dapat membantu setiap peserta didik memahami dan mencari contoh materi yang sedang diajarkan dalam pembelajaran. Guru memanfaatkan media teks karenabagi setiap guru teks yang digunakan memudahkan siswa untuk mendapatkan pembelajaran yang maksimal. Walaupun media teks di kurikulum sekarang lebih sedikit penggunaanya, namun guru tetap menggunakan jenis media ini. Seperti halnya dengan materi yang disampaikan oleh guru bahasa Indonesia di kelas VII A1 dan VII A2, guru menggunakan jenis media pembelajaran teks yang bersumber dari internet yaitu teks deskripsi dan teks prosedur.

Teks deskripsi yang digunakan oleh guru bahasa Indonesia pada saat mengajar, didapatkan melalui halaman web yang sebelumnya dicari melalui google. Teks deskripsi digunakan oleh guru mengenai hewan "Kucing".

Jadi, hasil yang telah didapatkan adalah jenis media yang sering digunakan dapat diketahui yaitu media video dan media teks yang bersumber dari internet melalui sumber yang berbeda. Media video yang digunakan oleh guru bersumber dari internet dengan memanfaatkan youtube untuk mencari video yang akan digunakan.

Dalam penelitian ini, penggunaan media internet sebagai bahan pembelajaran yang digunakan oleh guru di SMP Negeri 4 Singaraja sudah baik. Dalam pembelajaran bahasa Indonesia guru menggunakan media video dan teks sebagai bahan pembelajaran. Banyak pertimbangan guru dalam menggunakan media pembelajaran tersebut. Melalui gambar bergerak guru merasa sangat mudah untuk memberikan penjelasan mengenai materi menggunakan media video. Guru menjadi terbantu untuk menjelaskan isi dari materi yang diberikan. Selain itu guru melalui pemanfaatan internet mudah mencari sumber pembelajaran berupa video untuk diberikan kepada seluruh siswa. Tidak hanya video yang digunakan oleh guru namun, guru juga menggunakan media teks sebagai alat bantu untuk memberikan pemahaman materi lebih jelas. Penggunaan media teks yang bersumber melalui internet membantu guru dalam memberikan materi yang diajarkan.

Penelitian pertama dilakukan pada pada Kamis, 11 April 2019, jam pelajaran ke 3-4 (08.45-10.15 wita) di kelas VII A1. Dalam penelitian ini diperoleh tiga tahap pelaksanaan pembelajaran, yaitu pendahuluan, kegiatan inti, dan penutup. Berikut dijelaskan tahap-tahap penggunaan media internet sebagai sumber pembelajaran yang dilakukan oleh guru pada materi cerita fantasi.

Pada kegiatan pendahuluan terdapat lima kegiatan yang dilakukan oleh guru. Lima kegiatan tersebut dijelaskan sebagai berikut.Pertama, guru memasuki kelas dan peserta didik memberikan salam.Kedua, salam dibalas oleh guru.Ketiga, guru melakukan presensi.Keempat, guru meminta peserta didik membuka buku mengenai materi yang bersangkutan dan membaca materi yang di berikan oleh guru, lalu guru mengaitkan materi tersebut dengan kehidupan sehari-hari peserta didik (kegiatan apersepsi).Kelima, guru menyampaikan tujuan pembelajaran.

Pada kegiatan inti terdapat sepuluh kegiatan yang dilakukan oleh guru.Sepuluh kegiatan tersebut dijelaskan sebagai berikut.Pertama, guru meminta peserta didik untuk mendengarkan dan menyimak video yang guru tampilkan dilayar.Kedua guru meminta peserta didik bertanya mengenai materi yang telah ditampilkan di $L C D$. Ketigaguru menjawab pertanyaan dari peserta didik dengan mengaitkan materi yang diberikan.Setelah itu, keempatguru meminta peserta didik melihat contoh teks cerita fantasi di buku ajar, lalu peserta didik 
mengamati cerita fantasi tersebut.Kelima, setelah peserta didik mengamati cerita tersebut, guru memberikan contoh kembali mengunakan video yang guru cari secara langsung terhubung ke jaringan internet. Keenam, guru bertanya kepada salah satu peserta didik mengenai isi dari cerita fantasi tersebut. Kemudian, ketujuh peserta didik menjawab tugas yang ada di buku ajar tentang pemahaman mengenai cerita fantasi. Kedelapan peserta didik mengerjakan tugasnya, guru juga berkeliling melihat pekerjaan peserta didik sambil menjawab pertanyan-pertanyaan dari beberapa peserta didik. Setelah itu kesembilan, guru meminta peserta didik mencari contoh cerita fantasi dari internet yang berupa video.Kesepuluh, tugas tersebut dikumpulkan melalui whatsapp dengan waktu pengumpulan satu minggu.

Pada kegiatan penutup, guru melakukan evaluasi terhadap peserta didik dengan cara melakukan tanya jawab untuk meninjau kembali materi yang telah dipelajari. Guru memberitahukan jadwal ulangan harian mengenai materi cerita fantasi. Setelah itu, guru menyimpulkan pembelajaran.

Penelitian keduadilaksanakan pada Jumat,12 April 2019, jam pelajaran ke 3-4 (08.45-10.15 wita). Berdasarkan observasi yang dilakukan peneliti menemukan bahwa ada tiga tahap pelaksanaan pembelajaran, yaitu pendahuluan, kegiatan inti, dan penutup.Berikut dijelaskan tahap-tahap penggunaan media internet sebagai sumber pembelajaran yang dilakukan oleh guru pada materi teks deskripsi.Pada kegiatan pendahuluan terdapat lima kegiatan yang dilakukan oleh guru. Kelima kegiatan tersebut dijelaskan sebagai berikut.

Pertama, guru memasuki kelas dan peserta didik memberikan salam.Kedua, salam dibalas oleh guru. Ketiga, guru melakukan presensi.Keempat, guru meminta peserta didik membuka buku mengenai materi yang bersangkutan dan membaca materi yang di berikan oleh guru, lalu guru mengaitkan materi tersebut dengan kehidupan sehari-hari peserta didik (kegiatan apersepsi). Kelima, guru menyampaikan tujuan pembelajaran.
Dalam kegiatan inti terdapat sepuluh kegiatan yang dilakukan oleh guru. Sepuluh kegiatan tersebut dijelaskan sebagai berikut.Pertama, guru meminta peserta didik untuk mendengarkan dan menyimak video yang ditayangkan guru. Kedua, guru meminta peserta didik bertanya mengenai materi yang ditayangkan. Ketiga, guru menjawab pertanyaan dari peserta didik dengan mengaitkan materi yang diberikan.Setelah itu keempat,guru meminta peserta didik melihat contoh teks deskripsi yang telah diberikan oleh guru melalui hardcopy, lalu peserta didik mengamati teks tersebut.Kelima setelah peserta didik mengamati teks tersebut, guru memberikan contoh kembali menggunakan teks yang didapatkan secara langsung menggunkan jaringan internet. Keenam, guru bertanya kepada salah seorang peserta didik mengenai isi dari teks deskripsi yang diberikan. Kemudian, ketujuh peserta didik menjawab tugas yang ada di buku ajar tentang pemahaman mengenai teks tersebut.Kedelapan,peserta didik mengerjakan tugasnya, guru juga berkeliling melihat pekerjaan peserta didik sambil menjawab pertanyan-pertanyaan dari beberapa peserta didik. Setelah itu kesembilan,Guru meminta peserta didik mencari contoh teks deskripsi dari internet dan membuat satu teks deskripsi.Kesepuluh, tugas tersebut dikumpulkan melalui whatsapp dengan waktu pengumpulan satu minggu. Pada kegiatan penutup, guru melakukan evaluasi terhadap peserta didik dengan cara melakukan tanya jawab untuk meninjau kembali materi yang telah dipelajari. Guru memberitahukan jadwal ulangan harian mengenai materi teks deskripsi. Setelah itu, guru menyimpulkan pembelajaran.

Dari penelitian yang dilakukan di SMP Negeri 4 Singaraja mengenai data penggunaan internet dalam pembelajaran bahasa Indonesia, didapatkan hasil bahwa penggunaan internet dalam pembelajaran sangat bermanfaat. Manfaat yang didapatkan yaitu, mampu memberikan contoh kepada peserta didik, mencari sumber pembelajaran yang relevan, dan untuk mengirim tugas. Penggunaan media internet dalam pembelajaran yang 
diguanakn untuk memberikan contoh kepada peserta didik sangat membantu pemahaman peserta didik dalam mengikuti pembelajaran secara baik. Selain itu, peseta didik lebih paham mengenai materi yang dijelaskan oleh guru ketika mengajar. Dalam pembelajaran yang menggunakan sumber melalui internet sangat membantu guru untuk mencari bahan pembelajaran lebih mudah dan praktis, selain itu guru bisa mengunakan bahan pembelajaran melalui internet untuk menambah wawasan dan pengembangan teknologi yang semakin maju. Selain itu di era sekarang internet sudah tidak asing lagi. Tugas-tugas yang diberikan guru peserta didik akan dikirim melalui media internet whatsapp untuk lebih cepat dan lebih praktis.

\section{PEMBAHASAN}

Dari hasil penelitian yang didapat peneliti berdasarkan rumusan masalah, peneliti dapat membuat pembahasaan yang meliputi, yaitu jenis media yang digunakan oleh guru dalam pembelajaran bahasa Indonesia dan penggunan internet sebagai media dalam pembelajaran bahasa Indonesia.Berikut uraian pembahasaan selama pelaksanaan penelitian.

Setiap guru memiliki cara masingmasing untuk menyampaikan materi agar dapat diterima oleh peserta didik. Cara yang diberikan guru untuk menarik siswa dalam pembelajaran yaitu melalui media yang digunakan. Guru menggunakan media dengan cara memaparkan materi yang bersangkutan melalui power point atau video sebagai bahan pembelajaran. Guru menerangkan setiap point yang dipaparkan memberikan ransangan kepada siswa. Berdasarkan hasil wawancra tersebut mendapatkan hasil bawah guru menyampaikan media pembelajaran menggunakan video dan teks yang bersumber dari internet.

Dalam pembelajaran media yang digunakan sangat membantu setiap guru untuk memberikan pengajaran yang baik dalam proses belajar-mengajar. Media pembelajaran bermanfaat bagi peserta didik yang membantu dengan baik menerima materi yang diberikan. Jenis media yang digunakan seperti halnya dengan media video yang banyak membantu setiap guru yang akan menyampaikan materi. Seperti pembelajaran teks prosedur guru lebih menggunakan video yang bersumber melalui internet untuk menarik peserta didik lebih semangat dalam mengikuti pembelajaran.

Berdasarkan hasil wawancara pendapat yang diperoleh dari guru mengenai jenis media yang digunakan dapat membantu dengan baik dalam memberikan hasil belajar yang maksimal. Selain itu, siswa lebih memahami materi dari adanya media video yang digunakan dan siswa lebih giat belajar. Media internet dapat melengkapi pembelajaran konvensional saat peserta didik mencari informasi di internet dan menanggapi materi yang belum dipahami. Hasl ini sejalan dengan yang dikatakan (Haris, 2015) media pembelajaran internet digunakan secara konvensional untuk memberikan pemahaman yang mudah bagi setiap peserta didik. Informasi yang didapatkan oleh peserta didik disampaikan saat pertemuan di dalam kelas, jika ada yang kurang atau salah maka guru akan menanggapi informasi tersebut supaya peserta didik bisa lebih memahaminya. Jika guru mengunggah materi di whatsapp dan terdapat pertanyaan dari peserta didik maka guru menanggapinya juga melalui pertemuan tatap muka.

Pemanfaatan internet sebagai media dalam pembelajaran bahasa Indonesia sangat membantu sebagai sumber informasi materi pelajaran bagi guru untuk mencari materi-materi yang sulit dan buku tidak mencakup keseluruhan materi pelajaran. Saat hal itu terjadi maka guru memanfaatkan internet sebagai sumber informasi.Kendala yang sering dihadapi dalam menggunakan media elektronik seperti memanfaatkan fasilitas internet yang sering menjadi permasalahan adalah jaringan yang masih belum memadai untuk mengakses internet. Selain itu kebanykan guru yang masih hawam dengan adanya teknologi yang semakin maju. 
Dengan demikian, kendala yang sering dihadapi oleh guru yaitu jaringan yang masih belum terjangkau karen biaya yang tinggi, ketika aliran listrik sedang dalam perbaikan pemggunaan internet dan jenis media lainnya akan menjadi terhambat. Oleh karena itu, pembelajaran bahasa Indonesia dengan memanfaatkan jenis media inernet dalam pembelajaran hasilnya lebih maksimal.

penggunaan media pembelajaran yang sering digunakan oleh guru lebih mengunakan media proyeksi karena media ini langsung berinteraksi dengan pesan yang ingin disampaikan. Maksud pesan ini tentu saja materi pelajaran yang akan disampaikan. Jadi, guru menggunakan media proyeksi agar materi tersebut dapat diserap dengan baik. Selain media proyeksi yang digunakan oleh guru, media bukan proyeksi juga digunakan agar peserta didik dapat lebih jelas memahami maksud yang diberikan. Hal tersebut sejalan dengan pernyataan (Maman, 2010) bahwa dari segi pemakaiannya, media dapat dikelompokkan ke dalam media proyeksi dan bukan proyeksi.

Penggunaan media sebagai bahan pembelajaran membantu siswa dalam memahami dan lebih membangun minat belajar siswa. Guru SMP Negeri 4 Singaraja menggunakan media pembelajaran video dan teks yang bersumber melalui internet untuk bahan pembelajaran. Dalam penggunaan media video yang digunakan oleh guru menjadi sangat mudah untuk menyampaikan materi pembelajaran. Guru menggunakan video tersebut secara berulang-ulang di masing-masing kelas. Video yang digunakan oleh guru yaitu video cerita rakyat yang sangat membangun karakter yang dimiliki oleh setiap siswa. Untuk menyampaikan materi ini, digunakanlah rekaman video dan alat pemutarnya, baik berupa laptop dengan LCD maupun VCD dengan televisi.

\begin{tabular}{lrrr}
\multicolumn{2}{c}{ Selain video, } & \multicolumn{1}{c}{ guru } & juga \\
menggunakan media & $\begin{array}{r}\text { teks } \\
\text { yang }\end{array}$ \\
bersumber melalui & internet. & Guru \\
menggunakan teks & sebagai & media \\
pembelajaran kepada & siswa & untuk \\
memberikan & contoh & materi & yang
\end{tabular}

bersangkutan. Guru menggunakan media teks karena selain media visual yang diperlihatkan oleh guru kepada siswa, media teks juga membantu siswa dalam pemahaman suatu materi. Pada kegiatan yang di lakukan saat mengajar, media teks diguakan sebagai contoh dan guru membarikan peserta didik untuk mencari hal-hal yang berkaitan dengan materi yang diajarkan.

Dalam kegiatan pembelajaran guru menggunakan ketiga video tersebut dengan penyesuaian kompetensi dasar yang digunakan. Setiap video yang digunakan oleh guru memeliki perbedaan. Seperti halnya dengan video cerita fantasi yang digunakan oleh guru berbeda dengan video deskripsi. Video yang digunakan oleh guru tersebut memiliki perbedaan sesuai materi yang diajarkan. Namun, pada bagian penyampaian materi di setiap indikator guru menggunakan ketiga video tersebut sebgai contoh dalam pembelajran dan digunakan sesuai dengan rancangan yang dibuat oleh guru tersebut.

Sama halnya dengan media teks yang digunakan oleh guru. Guru menggunakan media teks yang berbeda karena pada materi yang diajarkan tidak memiliki kesamaan substansi. Dalam teks yang diberikan guru kepada siswa cara penggunaannya masih sama, yaitu guru hanya menggunakan teks tersebut sebagai contoh dalam pembelajaran.

Jadi, dari pembahasan tersebut dapat disimpulkan bahwa jenis media yang digunakan seperti video dan teks bersumber melalui internet. Guru menggunakan media tersebut dimasingmasing kelas dalam pembelajaran. Selain itu, guru menggunakan media tersebut sebagai contoh dalam pembelajaran. Guru menggunakan internet dalam pembelajaran hanya mencari media yang digunakan dan guru masih menggunakan buku ajar sebagai pedoman pembelajaran.

Melihat fenomena di atas, penelitian ini tentu memiliki implikasi terhadap pembelajaran dengan memanfaatkan teknologi dan media internet. Hasil penelitian mengenai penggunaan internet 
sebagai media dalam pembelajaran bahasa Indonesia menunjukkan hasil sangat efektif. Hal ini memiliki implikasi bagi guru dan siswa. Selama ini, guru hanya memanfaatkan media internet hanya sebagai tempat mengirim materi tambahan, tugas, dan pemberitahuan mengenai akan diadakannya ulangan.

Dengan diadakannya penelitian ini, dapat memberikan dampak yang baik dalam mengatasi masalah tersebut. Untuk mengatasi permasalahan tersebut, diperlukan adanya usaha dan upaya dari pihak guru dalam meningkatkan kualitas pembelajaran dengan pemanfaatan internet sebagai media pembelajaran dengan cara memberikan pemahaman lebih untuk mencari sumber dari internet agar mendapatkan pemahaman yang lebih baik, setelah itu guru bisa meminta siswa untuk membacakan hasil yang dicari untuk dibahas dipertemuan tatap muka. Selain itu, guru juga dapat memberikan imbalan berupa penambahan nilai bagi yang bertanya dan mampu menjawab pertanyaan yang diberikan terkait materi yang diminta untuk mencri sumber melalui media internet. Selain itu, dengan adanya penelitian ini perlu kiranya dilakukan penelitian lebih lanjut mengenai pemanfaatan teknologi dan media internet sebagai media dalam pembelajaran.

\section{SIMPULAN DAN SARAN}

Berdasarkan analisis terhadap data hasil penelitian pada kelas VII A1 dan VII A2 di SMP Negeri 4Singaraja dengan penggunaan internet sebagai media dalam pembelajaran bahasa Indonesia, dapat ditarik simpulan sebagai berikut. 1) Jenis Media Berbasis Internet yang digunakan Guru dalam Pembelajaran Bahasa Indonesia di Kelas VII SMP Negeri 4 Singaraja berdasarkan hasil penilaian yang dilakukan oleh guru, dari hasil penelitian yang menggunakan pedoman wawancara di dapatkan hasil bahwa guru bahasa Indonesia lebih banyak menggunakan video dan teks sebagai jenis media berbasis internet yang sering digunakan. Jadi, dapat disimpulkan bahwa jenis media yang sering digunakan oleh guru dalah jenis media berupa video dan teks. 2) Penggunaan Media Internet dalam Pembelajaran Bahasa Indonesia di Kelas VII SMP Negeri 4 Singaraja, selain video yang digunakan oleh guru, media yang bersumber melalui internet juga digunakan guru seperti halnya dengan teks. Guru menggunakan teks sebagai media pembelajaran kepada siswa untuk memberikan contoh materi yang bersangkutan. Guru menggunakan media teks karena selain media visual yang diperlihatkan oleh guru kepada siswa, media teks juga membantu siswa dalam pemahaman suatu materi. Pada kegiatan yang di lakukan saat mengajar, media teks diguakan sebagai contoh dan guru membarikan peserta didik untuk mencari hal-hal yang berkaitan dengan materi yang diajarkan.

Selain itu, dilihat dari yang dilakukan guru saat mengajar, guru juga lebih sering menggunakan buku ajar dalam pembelajaran. Guru menggunakan internet hanya sebagai media contoh dalam pembelajaran. Guru memanfaatkan fasilitas internet hanya pada saat mencari sumber pembeljaran. Untuk melaksanakan pengiriman tugas atau pemberian tugas guru juga tidak begitu sering, karena guru masih menggunakan sistem manual untuk mengirim tugas.Dalam pembelajaran guru menggunakan media internet video dan teks sebagai bahan pembelajaran yang membuat siswa menjadi lebih mengerti.

Berdasarkan hasil penelitian terhadap penggunaan internet sebagai media dalam pembelajaran bahasa Indonesia di SMP Negeri 4 Singaraja, maka peneliti memberikan saran untuk pihak-pihak terkait antara lain sebagai berikut: 1)Bagi guru bahasa Indonesia, penelitian ini diharapkan dapat memberikan masukan bagi guru-guru supaya lebih efektif dalam menerapkan internet sebagai mediadi sekolah dan menjadi pedoman untuk melaksanakan pembelajaran e-learning. 2) Bagi peserta diharapkan mampu berperan aktif dalam kegiatan pembelajaran,dengan begitu penggunaan internet sebagai mediaakan meningkatkan hasil belajar peserta didik. 3) Bagi sekolah, pembelajaran inidiharapkan mampu meningkatkan kualitas sekolah 
menjadi sekolah yang memiliki daya saing di era global. 4) Bagi orang tua, jangan meremehkan kualitas internet yang dipandang negatif bagi anak-anak. Lihatlah dari segi positif yang dihasilkan.

\section{DAFTAR PUSTAKA}

Essti, Ismawanti. 2011. Metode Penelitian Pendidikan Bahasa \& Sastra Indonesia. Yogyakarta: Ombak.

Haris, Budiman. 2015. Peran Teknologi Informasi dan Komunikasi dalamPendidikan. Dalam http:// ejournal.radenintan.ac.id/index.php/tad zkiyyah/article/download/2095/1584. Diakses pada 1 Maret 2019.

Kaliky. 2013. Pemanfaatan Internet Sebagai Media. Dalam https:// media. neliti. com /media/publications/92442-IDmanfaat-internet-sebagai-mediakomunikas.pdf. Diakses 11 Maret 2019.

Rohaya. 2008.Internet: Pengertian, Sejarah, Fasilitas dan Koneksinya. Dalam http: //digilib.uinsuka.ac.id/362/1/INTERNET \%20PENGERTIAN\%2C\%20SEJARAH $\% 2 \mathrm{C} \% 20 \mathrm{FASILITAS} \% 20 \mathrm{DAN} \% 20 \mathrm{KON}$ EKSINYA.pdf. Diakses pada 12 Maret 2019

Setyani, 2010. Perkembangan Pendidikan. Dalam https://lib.unnes.ac.id/8416/ 1/11071a.pdf. Diakses 13 Maret 2019.

Suandi, I Nengah. Dkk. 2016.PEDOMAN PENULISAN KARYA ILMIAH. Singaraja: Undiksha.

Suandi, I Nengah. 2008. Buku Ajar Penelitian Pendidikan Bahasa dan Sastra Indonesia. Singaraja: Undiksha.

Talika, 2016. Peran guru dalam pendidikan. Dalam http: //semnasfis. unimed.ac.id/ wpcontent/uploads/2016/06/PERANAN -GURU-DALAM-PEMBELAJARAN.pdf. Diakses 1 Maret 2019.

Wendra. 2016. Buku Ajar Penulisan Karya IImiah. Singaraja: Undiksha. 